\title{
Binary Discourse in U.S. Presidential Speeches from FDR to Bush
} II

\author{
Dr. Wassim Daghrir, \\ The University of Sousse, Tunisia
}

\section{Introduction}

The contemporary study of American Presidential rhetoric is of great significance. Politics is very largely the use of language. Presidential speech and action increasingly reflect the opinion that speaking is governing. In fact, the power of the presidency depends on its ability to persuade. The application of power is often legitimized through rhetorical persuasion; and, in the case of American Presidents, such power, and its associated rhetoric, becomes the fulcrum upon which many global issues turn.

\section{Manichaeism: a Definition}

The term Manichean refers in its most literal sense to a religion founded in the third century by the Persian prophet Manes. The movement attracted large numbers of followers, who were drawn to its simplicity and moral clarity. Its central guideline was that the entire world could be plainly divided into two opposing spheres -God and Satan in the world of the eternal, and a corresponding dualistic battle of Good and Evil playing out on Earth. World events were all driven by, were all the product of, an ongoing, endless conflict between the forces of Good and the forces of Evil. One's moral duty was to maintain adherence to God's will by siding with Good and battling against the forces of Evil.

\section{Rhetorical Devices and Manipulations}

At the heart of the American presidential discourse exists a coherent worldview, one several presidents have applied with remarkable consistency and uncompromising conviction. This view holds that the global arena can be understood as a conflict between the forces of Good and Evil, and that America is "called upon" to defend the former from the latter. By definition, this premise requires the identification of Evil, which is the enemy -an enemy that is pure in its Evil and that, by its very nature, cannot be engaged, offered compromises, negotiated with, understood, managed, contained, or ignored. It can only be hated, attacked, and destroyed. One way of achieving this is by using 'legitimizing language' -language that will positively represent the favored worldview or the approved approach to global phenomenon as well as those who support this view or approach. The use of legitimizing language is usually accompanied by the use of its counterpart, 'delegitimizing language' -language which negatively depicts the opposing worldview or approach as well as those who hold these different opinions and values. Therefore, binary conceptualizations frequently take on the form of a polarization between a legitimized insider group ('us') and a delegitimized outsider group ('them'). ${ }^{1}$

Some of the most significant presidential speeches, such as President Harry Truman's March 1947 speech, President Ronald Reagan's 1982 "Evil Empire" speech, and President George W. Bush's 2002 "Axis of Evil" speech, pictured a Manichean world of Light and Darkness, White and Black, with no shades of grey. Nazism, Communism, Terrorism, and all the "isms" on the targets list represent a demonic force candidly opposed to all that was good, true, right, and pure. With such a force, there should be no compromise, no halfway measures.

The choice facing America, President Truman argued in March 1947, was between two opposing and irreconcilable ways of life, between the virtues of democracy and the horrors of totalitarianism. In this way, President Truman manifested the Manichean outlook toward external political developments. ${ }^{2}$

President Ronald Reagan adopted the same dichotomous fashion, when he referred to the Soviet Union as an "Evil Empire". By making such a rhetorical distinction, he gave overt identity to a tacit concept that dominated the Cold War for decades: the concept of Global Manichaeism. In a bipolar world struggle, the characterization of the Soviet Union as Evil automatically applied the opposite identity of Goodness to the United States, thereby creating a palpable Manichaean paradigm. ${ }^{3}$

In this same vein, President George W. Bush argued in a January 2002 speech:

\footnotetext{
${ }^{1}$ Tanja Collet, and Tom Najem, Word Choices in Post-9/11 Speeches and the Identity Construction of the Other (http://www.cpsaacsp.ca/papers-2005/Najem.pdf)

${ }^{2}$ See Appendix: BINARY MANICHAEISM IN U.S. PRESIDENTIAL SPEECHES

${ }^{3}$ Ibid.
} 
You know, you've heard me talk about this probably, but I really, truly view this as a conflict between Good and Evil. And there really isn't much middle ground. The people we fight are evil people. ${ }^{4}$

Actually, Bush's World View is a paragon of Manichaeism. George II's belief that America had embarked upon a binary struggle of Good vs. Evil was the predominant theme of his presidency. The president and his administration invoked this starkly dualistic theme repeatedly to defend and justify a whole host of controversial actions. On September 20, 2001, the president addressed a joint session of congress and made clear that not only was the conflict America faced one between pure good and pure evil, but further, everyone was compelled to choose one side or the other: "every nation, in every region, has now a decision to make. Either you are with us, or you are with the terrorists."

President Bush underscored the binary nature of the challenge facing America again in his January 29, 2002 State of the Union speech. He announced that US foreign policy would be devoted primarily to combating the threats posed by an "axis of evil" threatening the world:

States like these [North Korea, Iran, and Iraq], and their terrorist allies, constitute an axis of evil, arming to threaten the peace of the world. By seeking weapons of mass destruction, these regimes pose a grave and growing danger. They could provide these arms to terrorists, giving them the means to match their hatred. They could attack our allies or attempt to blackmail the United States. In any of these cases, the price of indifference would be catastrophic... ${ }^{6}$

The president's speech made it emphatically clear that America's enemies were not merely hostile to the US and threatening its interests but rather were pure evil. They did not operate in isolation but as an "axis", the historically familiar term designating Hitler's Germany and its allies. America's enemies were intent on America's total destruction and they were all part of one unified mass. Above all, the US was to be governed by an absolute truth: "we've come to know truths that we will never question: evil is real, and it must be opposed." And in a speech announcing his controversial Pre-emptive Strikes Doctrine, President Bush defended his Manichean world view as such:

Some worry that it is somehow undiplomatic or impolite to speak the language of right and wrong. I disagree. [...] We are in a conflict between good and evil, and America will call evil by its name. By confronting evil and lawless regimes, we do not create a problem, we reveal a problem. And we will lead the world in opposing it. ${ }^{8}$

This kind of binary rhetoric is rooted in the nation's puritan tradition as prophetic dualism through which the world is divided into two opposite camps. The generic features that have endured in such Manichean approach are the following:

(1) An appeal to a legitimate power source that is external to the orator, and which is presented as inherently Good.

(2) An appeal to the historical importance of the culture in which the discourse is located.

(3) The construction of a thoroughly evil other.

(4) A unifying construct (religious, racial, political, philosophical, or nationalistic) that appeals for unification. 9

Furthermore, the major Manichean speeches share several important connotations:

First, a religious tenet or dogma: major presidential speeches have constantly exhibited high religious-moral content. President Truman's March 1947 speech, for example, clearly had religious-moral connotations. It grew out of a conviction that international politics were dominated by a clash between two totally dissimilar and antithetical value systems. Nations of the world, Truman maintained, were being compelled to choose "between 2 alternative ways of life" represented by the US and the Soviet Union. Truman believed that the Communist menace was as dangerous for the American society as the earlier Axis threat. In this way, Truman's Manichean rhetoric proclaimed a new diplomatic crusade. ${ }^{10}$

In this same vein, President Reagan told the people of West Berlin in June 1982 that theirs was "a meeting place of light and shadow, tyranny and freedom. To be here is truly to stand on freedom's edge and in the shadow of a

\footnotetext{
${ }^{4}$ See Appendix: BINARY MANICHAEISM IN U.S. PRESIDENTIAL SPEECHES.

${ }^{5} \mathrm{Ibid}$.

${ }^{6}$ Ibid.

${ }^{7}$ Ibid.

${ }^{8}$ Ibid.

${ }^{9}$ Graham, Philip, Keenan, Thomas and Dowd, Anne-Maree, “A call to arms at the End of History: A discourse-historical analysis of George W. Bush's declaration of war on terror", Discourse \& Society, 2004, pp. 199-221.

${ }^{10}$ See Appendix: BINARY MANICHAEISM IN U.S. PRESIDENTIAL SPEECHES.
} 
wall that has come to symbolize all that is darkest in the world today, to sense how shining and priceless and how much in need of constant vigilance and protection our legacy of liberty is". In Reagan's words, "the forces of good" must ultimately rally if they are to "triumph over evil". The "great civilized ideas" of "individual liberty, representative government, and the rule of law under God" are "menaced" by an "evil neighbor". Communism, like Fascism, has glorified "the arbitrary power of the state" while denying "the existence of God" and "those God-given liberties that are the inalienable right of each person on this planet". Theirs is a "totalitarian evil", an "ideology... without God"."1

Many of President George W. Bush's speeches were filled with references to the United States being "called" or given a "mission" by the "Maker of Heaven" and "Author of Liberty." Bush's speeches have exceeded those of his predecessors in the sheer number of references to God, but there was nothing unusual in a U.S. president describing the nation's role in the world in religious terms. And many U.S. presidents have invoked the same mission - that the United States, as the "city upon a hill" and the "indispensable nation" has been called by God to achieve "the expansion of freedom in the entire world." As a matter of fact, the US has traditionally allowed religious conceptions not only to dictate ultimate goals but to color its understanding of the real world in which these goals have to be met. ${ }^{12}$

A second common connotation of the Manichean speeches is a forceful assertion of the ideological principles advocated by the American society: Indeed, the diplomatic speeches of the US have exemplified ideological and political principles deeply embedded in the American culture. Americans expect their interventions to be grand heroic crusades on a worldwide scale, a struggle between Light and Darkness with the fate of the world hanging on the outcome. In fact, a nation that has historically condemned power politics as immoral and as a corruption of the democratic ideal needs a moral basis for its use of power.

A third common feature of the Manichean discourse has been its highly ambivalent and flexible character: The vagueness and imprecision characteristic of presidential rhetoric has in some instances been intentional. The speeches of American foreign policy have exemplified "masterful ambiguity": they were designed to serve as highly flexible and adaptive policy instruments, affording officials in Washington maximum freedom to interpret and apply them to a wide range of diverse conditions abroad.

\section{Justifications}

Such notions as "world leadership", "American Mission", "America's embodiment of Good and its ideals" are often advanced to justify the Manichean dichotomy. We may identify several explicit tenets of American political ideology which have been reflected in the nation's most significant presidential speeches:

\section{"American Exceptionalism"}

The belief in American Exceptionalism provides an essential element of the cultural and intellectual framework for the making and conduct of U.S. foreign policy. It has always had a powerful presence in American discourse. Every president has invoked the theme of a unique America in some way or another. Consequently, a recurring theme is that foreign policy choices are made for moral reasons. At a minimum, Exceptionalism assumes that the United States is morally and culturally equipped to offer an example to the world. More proactive interpretations of Exceptionalism support the promotion of American values abroad through the use of various aspects of US power and influence.

President Ronald Reagan, for instance, explicitly adopted the American Exceptionalist rhetoric, insisting that America is indeed a shining city on a hill:

The past few days when I've been at that window upstairs, I've thought a bit of the "shining city upon a hill." The phrase comes from John Winthrop, who wrote it to describe the America he imagined. What he imagined was important because he was an early Pilgrim, an early freedom man. He journeyed here on what today we'd call a little wooden boat; and like the other Pilgrims, he was looking for a home that would be free.

I've spoken of the shining city all my political life, but I don't know if I ever quite communicated what I saw when I said it. But in my mind it was a tall, proud city built on rocks stronger than oceans, windswept, God-blessed, and teeming with people of all kinds living in harmony and peace; a city with free ports that hummed with commerce and

\footnotetext{
${ }^{11}$ See Appendix: BINARY MANICHAEISM IN U.S. PRESIDENTIAL SPEECHES

${ }^{12}$ In his inaugural address, John Adams thanked an "overruling Providence which had so signally protected this country from the first." In 1919, Woodrow Wilson promised that through supporting the League of Nations, the United States would lead in the "redemption of the world." During World War II, Roosevelt declared in his 1942 message to Congress: "We on our side are striving to be true to [our] divine heritage."
} 
creativity. And if there had to be city walls, the walls had doors and the doors were open to anyone with the will and the heart to get here. That's how I saw it, and see it still.

And how stands the city on this winter night? More prosperous, more secure, and happier than it was 8 years ago. But more than that: After 200 years, two centuries, she still stands strong and true on the granite ridge, and her glow has held steady no matter what storm. And she's still a beacon, still a magnet for all who must have freedom, for all the pilgrims from all the lost places who are hurtling through the darkness, toward home. ${ }^{13}$

\section{The Power of America's "Example"}

A major ideological component of the American foreign policy rhetoric has been the conviction that the American way of life represents a model for mankind and is destined to become universally adopted. The Truman Doctrine speech, for instance, indicated a belief that the principles of the American Revolution, rather than Communist revolutionary strategies, should guide foreign societies seeking to achieve internal political freedom. In fact, the belief that America serves as a moral paradigm, or model, for the rest of the world has continued to be a major component of the national conscience. It validates the convictions that the United States is morally qualified for world leadership.

\section{The American "Mission"}

One of the foundations of America's sense of its Exceptionalism is that the US has an obligation to somehow take care of the rest of the world. This paternalistic outlook has developed out of the core belief that the US is inherently more virtuous and righteous than other states. The Second World War offered a clear case for the application of America's vindicator identity in the name of international morality. President Roosevelt invoked the crusade motif in order to justify American entry into the war. America's crusade was not only in the interests of the US, it was for the good of the world. America's mission was seen as synonymous with the interests of the free world, and this fusion signaled the beginning of the monopoly of the vindicator representation that has since dominated US foreign policy.

In a 1945 speech, President Truman declared that the United States should "take the lead in running the world the way the world ought to be run."14 President Truman expressed America's "feeling of duty towards the civilized world". The Truman Doctrine's speech had an unmistakable "messianic" flavor: not only was the US determined to defend its own freedom, but it felt obliged to act as the defender of "freedom everywhere" throughout the world.

President John F. Kennedy also defended the idea America's mission to the civilized world in his State of the Union Message of 1962, when he declared: "people everywhere look to us -not to our wealth or power, but to the splendor of our ideals. For our nation is commissioned by history to be either an observer of freedom's failure or the cause of its success". ${ }^{15}$

President George W. Bush explicitly and repeatedly described the commitment to wage war not merely in terms of a strategy to make America safe but also as a "calling": "America is a nation with a mission, and that mission comes from our most basic beliefs." 16

\section{A Sense of Moral Certitude}

\section{Functions and Motivations}

Manichean leaders, by definition, believe that they are acting in pursuit or defense of the Good and against Evil. In this way, the binary dualism would have a moral function: to offer its holders a sense of moral certitude, which leaves no room for doubt or regret.

\section{War Justification}

The discourse rooted in Good and Evil legitimates any action undertaken in the name of good, no matter how destructive, on the grounds that it is attacking 'evil.' By clearly distinguishing two distinct sides to the global perspective, a binary opposition leaves no room for different interpretations. This simplistic prism positions the United States as the bastion of goodness and defender of righteousness in the world. Notably, such dramatic binary opposition seems likely to facilitate the assuaging of guilt associated with war. As Professor

\footnotetext{
${ }^{13}$ See Appendix: BINARY MANICHAEISM IN U.S. PRESIDENTIAL SPEECHES.

${ }^{14}$ President Truman quoted in Charles W. Kegley and Eugene R. Wittkopf, American Foreign Policy: Pattern and Process (New York: St. Martin's Press, $4^{\text {th }}$ Edition, 1991).

${ }^{15}$ See Appendix: BINARY MANICHAEISM IN U.S. PRESIDENTIAL SPEECHES.

${ }^{16} \mathrm{Ibid}$.
} 
Robert Ivie argues, "Americans traditionally have exonerated themselves of any guilt for war by decivilizing the image of their adversaries. This 'victimage ritual,' enacted with generic regularity, has...legitimized total victory over a foe who is totally uncivilized and therefore perfectly evil."17

\section{The Simplification of Complex Events, Decisions, and Acts}

Binary discourses simplify often complex external questions in a manner which is consonant with the American approach to foreign issues, given that the ordinary American has little sustained interest in or understanding of foreign affairs. Indeed, the binary, demonizing and reductionist discourse is meant to simplify complex events in order to "sell" certain unacceptable policies to an uninformed and deeply religious audience. What makes this type of communication so important is its capacity to create a false dilemma; that is, binary constructions present a limited view of the world and, often, force a decision between two options that, in actuality, are not the only outcomes available. In this way, a Good versus Evil battle is much more likely to gain the attention and approval of the American public, since it reduces a potentially complex scenario to an easily accessible question of morality and identity.

\section{Manichaeism as a Strategic Political Communication Device to Mobilize Public Opinion}

Political leaders can adopt the language of Manichean moralism as a tool for persuading citizens of the necessity and justifiability of certain actions. Controversial actions that, in fact, have little or nothing to do with a concern for good and evil can nonetheless be rhetorically justified via a dualistic appeal. Thus, issues can be framed in Manichean terms to manipulate public opinion, to cast morally neutral or even immoral policies as necessary for defense of the good, and to thereby generate support for actions they wish to undertake.

The Good vs. Evil, "We" vs. "them" approach serves dramatically to mobilize public support for a course of action deemed essential in foreign affairs. Moreover, it plays an essential role in promoting national unity on key foreign policy issues. Indeed, usage of binary communications as a means to unite groups against an enemy or in favor of a policy has been a recurring strategy in modern politics. Based on simple, unsophisticated, and often-misleading perceptions, the discourse rooted in Good and Evil offers a public relations device - actually a mass deception device- meant to prepare the American people psychologically for such extensive, continuing and unforeseen overseas commitments, such as the "Containment of Communism" and the "War on Terrorism". In an almost pavlovian way, the binary discourse manufactures retaliatory feelings and heats up war fever among the masses. ${ }^{18}$

Fear Appeals to Accomplish Domestic Persuasion

US presidents have always relied on fear tactics and emotional appeals to manufacture popular consent and to advance their internationalist, hegemonic agendas. The White House's political rhetoric and that of its supporters in the mass media almost uniformly conforms to a binary framework that mobilizes public opinion, sustains allegiance and justifies the actions of its leaders.

In March 1947, US President Harry Truman was preparing to launch a major foreign policy orientation that would define US foreign policy in the post World War II era and beyond. It was based on a new active and ambitious American involvement in world affairs. To secure the support of the American people for the dramatic sweep of the new policy, Truman readily understood that he needed not only to define his doctrine in terms of broad commitment to defend American values of freedom and individual liberties, but also to "scare the hell out of the country"19. The Truman Doctrine was as sweeping a commitment as the United States had ever made. It was the official declaration of a Cold War that defined the balance of power in international relations for over forty years. And it was based on the exaggeration of the Soviet threat and the exploitation of the American people's fear of that threat.

Clearly, the Bush Junior administration and the mainstream media whipped up fear and panic in their post-9/11 proliferation of reports of terrorist threats, obsessive focus on terrorism, and demands for retaliation. The media became weapons of mass hysteria that created tremendous fear in the population, which made the public look anxiously to the government for protection, rendering the population open to manipulation. In effect, after the September 11 strikes, the Bush administration used fear tactics to advance its aggressive political agenda.

\footnotetext{
${ }^{17}$ Cited in Kevin Coe, David Domke, Erica Graham, Sue John, and Victor Pickard, "No Shades of Gray: The Binary Discourse of George W. Bush and an Echoing Press", Journal of Communication, January 2006, pp. 234-252.

${ }^{18}$ By itself, the Good vs. Evil paradigm persuaded many Americans to support the invasion of Iraq in spite of the total absence of any concrete evidence to back up the administration's claims. The demonization of Saddam as pure Evil was so effective in precluding rational debate that, according to a USA Today poll in September 2003 (6 months after the us invaded Iraq), almost $70 \%$ of the country embraced the false belief that Saddam Hussein personally participated in the planning of the $9 / 11$ attacks. In effect, the president's all-consuming Manichean rhetoric planted a falsehood in the minds of most Americans -namely that Iraq was connected to the 9/11 attacks.

19 Truman sought and received advice from congressional leaders as he prepared to launch his doctrine. Truman was most impressed with the advice he received from Senator Arthur Vandenberg: "Mr. President," said Vandenberg, "the only way you are ever going to get this is to make a speech and scare the hell out of the country."
} 


\section{To Marginalize Criticism and Weaken Dissent}

The binary view of good and evil comes not merely to define every significant political issue but to engulf all political debate. One is presented with a false choice: embrace and actively support the president's policies to wage war on Evil (patriotism) or side with evil, either deliberately or by default (un-American / unpatriotic). Stressing national unity and patriotism provides rhetorical cover for suppressing dissent, and thus threatens U.S. democracy.

\section{Effects and Perils of the Dichotomous Framework}

\section{Belief in Moral Rightness and Lack of Flexibility and Pragmatism}

One of the principle dangers of vesting power in a leader who is convinced of his own righteousness who believes that he has been called to a crusade against evil- is that the moral imperative driving the mission will justify any and all means used to achieve it. Those who have become convinced that they are waging an epic and passionate existential war against evil cannot, by the very premises of their belief system, accept any limitations -moral, pragmatic, or otherwise- on the methods adopted to triumph in this battle.

In his book The Conservative Soul, political scientist Andrew Sullivan notes: "The essential claim of the fundamentalist is that he knows the truth. The fundamentalist doesn't guess or argue or wonder or question. He doesn't have to. He knows...". ${ }^{20}$ In fact, serenity flows and anxiety is eliminated by the conviction that one has found absolute truth Moral rightness trumps pragmatic success, and the imperatives of the crusade trump the constraints of reality.

Furthermore, embracing a core, unshakable conviction of one's own rightness legitimizes some of the most amoral and ethically monstrous policies, justified as necessary means to achieve a morally imperative end. Those who believe that they are on the path of righteousness, who are crusaders for the objective Good, will frequently become convinced that there can be no limitations on the weapons used to achieve their ends. The moral imperative of their agenda justifies all steps undertaken to fulfill it. Intoxicated by his own righteousness and therefore immune from doubt, the Manichean warrior becomes capable of acts of moral monstrousness that would be unthinkable in the absence of such unquestionable moral conviction. One who believes himself to be leading a supreme war against evil on behalf of good will be incapable of understanding any claims that he himself is acting immorally.

Bush himself explained that the certainty his faith brings liberates him from doubt and anxiety about the courses of action he pursues. He declared in his book, A Charge to Keep: "my faith frees me... frees me to make decisions others might not like. Frees me to do the right thing, even though it will not poll well". ${ }^{21}$

For the Manichean believer, the battle between Good and Evil is paramount. It subordinates all other considerations and never gives way to any conflicting or inconsistent goals. Measures intended to promote Good or undermine Evil are, by definition, necessary and just. They cannot be abandoned for pragmatic or prudential reasons, or because of growing opposition, or in response to evidence of failure. In sum, complexities, pragmatic considerations, the restraints of reality are trumped by the imperative of the moral crusade.

\section{Entitlement to Power}

From the president's overarching conviction that he is on the side of Good emerges a relentless pursuit of maximum power and an accompanying sense of entitlement to that power. Indeed, when expressed and implemented as a governing philosophy, this belief in the centrality of Good vs. Evil results not in an effort to limit government power, but rather to expand it drastically, both domestically and abroad, in order to accumulate power in service of the battle against perceived Evil and to impose perceptions of Good.

\section{The Manichean Paradox}

The great and tragic irony of the Manichean approach is that its foundations have generated some of the most morally grotesque acts and radical departures from American values. What is "good" and what is "evil" are not determined by some preordained or intrinsic distinction. Those are designations determined only by one's conduct. America has always advanced its principles as the source of its moral credibility in the world. But once those principles are relinquished and violated, America's moral credibility and its legitimate claim to "good" cease to exist.

In point of fact, General Herman Goering, a member of the Nazi Party, said it all in 1938:

\footnotetext{
${ }^{20}$ Andrew Sullivan, The Conservative Soul (NY: HarperCollins Publishers, 2006).

${ }^{21}$ George Bush, A Charge to Keep: My Journey to the White House (NY: HarperCollins Publishers, 2000).
} 
"Naturally the common people don't want war: Neither in Russia, nor in England, nor for that matter in Germany. That is understood. But, after all, it is the leaders of the country who determine the policy and it is always a simple matter to drag the people along, whether it is a democracy, or a fascist dictatorship, or a parliament, or a communist dictatorship. ... Voice or no voice, the people can always be brought to the bidding of the leaders. That is easy. All you have to do is tell them they are being attacked, and denounce the peacemakers for lack of patriotism and exposing the country to danger. It works the same in any country.",22

\section{APPENDIX 1: \\ BINARY MANICHAEISM IN U.S. PRESIDENTIAL SPEECHES ${ }^{23}$} (Illustrations)

FRANKLIN D. ROOSEVELT: The Arsenal of Democracy (December 29, 1940)

The Nazi masters of Germany have made it clear that they intend not only to dominate all life and thought in their own country, but also to enslave the whole of Europe, and then to use the resources of Europe to dominate the rest of the world. It was only three weeks ago that their leader stated this: "There are two worlds that stand opposed to each other." And then in defiant reply to his opponents he said this: "Others are correct when they say: 'With this world we cannot ever reconcile ourselves.' . . . I can beat any other power in the world." So said the leader of the Nazis.

In other words, the Axis not merely admits but the Axis proclaims that there can be no ultimate peace between their philosophy-their philosophy of government- and our philosophy of government [...].

Let us no longer blind ourselves to the undeniable fact that the evil forces which have crushed and undermined and corrupted so many others are already within our own gates [...].

We have no excuse for defeatism. We have every good reason for hope- hope for peace, yes, and hope for the defense of our civilization and for the building of a better civilization in the future.

\section{HARRY TRUMAN: The Truman Doctrine (March 12, 1947)}

At the present moment in world history nearly every nation must choose between alternative ways of life. The choice is too often not a free one.

One way of life is based upon the will of the majority, and is distinguished by free institutions, representative government, free elections, guaranties of individual liberty, freedom of speech and religion, and freedom from political oppression.

The second way of life is based upon the will of a minority forcibly imposed upon the majority. It relies upon terror and oppression, a controlled press and radio, fixed elections, and the suppression of personal freedoms. $[\ldots]$

The free peoples of the world look to us for support in maintaining their freedoms. If we falter in our leadership, we may endanger the peace of the world and we shall surely endanger the welfare of our own nation.

\section{John F. Kennedy's Inaugural Address Given on Friday, January 20, 1961}

Let every nation know, whether it wishes us well or ill, that we shall pay any price, bear any burden, meet any hardship, support any friend, oppose any foe, in order to assure the survival and the success of liberty.

"The Evil Empire", President Reagan's Speech to the House of Commons (June 8, 1982)

If history teaches anything, it teaches self-delusion in the face of unpleasant facts is folly. We see around us today the marks of our terrible dilemma--predictions of doomsday, antinuclear demonstrations, an arms race in which the West must, for its own protection, be an unwilling participant. At the same time we see totalitarian forces in the world who seek subversion and conflict around the globe to further their barbarous assault on the human spirit. What, then, is our course? Must civilization perish in a hail of fiery atoms? Must freedom wither in a quiet, deadening accommodation with totalitarian evil?

Statement by George W. Bush in his address to the nation on September 11, 2001

\footnotetext{
${ }^{22}$ Cited in Kevin Coe, The Language of Freedom in the American Presidency, 1933-2006 (Washington, D.C.:

${ }^{23} \mathrm{http}$ ://www.gpoaccess.gov/pubpapers/search.html
} 
Good evening. Today, our fellow citizens, our way of life, our very freedom came under attack in a series of deliberate and deadly terrorist attacks. [...] Thousands of lives were suddenly ended by evil, despicable acts of terror. [...]

America was targeted for attack because we're the brightest beacon for freedom and opportunity in the world. And no one will keep that light from shining.

Today our nation saw evil, the very worst of human nature. And we respond with the best of America.

\section{Remarks by President Bush on September 16, 2001}

Our nation was horrified, but it's not going to be terrorized. We're a great nation. We're a nation of resolve. We're a nation that can't be cowed by evil-doers. I've got great faith in the American people. If the American people had seen what I had seen in New York City, you'd have great faith, too. You'd have faith in the hard work of the rescuers; you'd have great faith because of the desire for people to do what's right for America; you'd have great faith because of the compassion and love that our fellow Americans are showing each other in times of need.

I also have faith in our military. And we have got a job to do - just like the farmers and ranchers and business owners and factory workers have a job to do. My administration has a job to do, and we're going to do it. We will rid the world of the evil-doers. We will call together freedom loving people to fight terrorism.

And on this day of - on the Lord's Day, I say to my fellow Americans, thank you for your prayers, thank you for your compassion, thank you for your love for one another. And tomorrow when you get back to work, work hard like you always have. But we've been warned. We've been warned there are evil people in this world. We've been warned so vividly - and we'll be alert. Your government is alert. The governors and mayors are alert that evil folks still lurk out there. [...]

We need to go back to work tomorrow and we will. But we need to be alert to the fact that these evil-doers still exist. We haven't seen this kind of barbarism in a long period of time. No one could have conceivably imagined suicide bombers burrowing into our society and then emerging all in the same day to fly their aircraft - fly U.S. aircraft into buildings full of innocent people - and show no remorse. This is a new kind of-- a new kind of evil. And we understand. And the American people are beginning to understand. This crusade, this war on terrorism is going to take a while. And the American people must be patient. I'm going to be patient. [...]

That's why I say to the American people we've never seen this kind of evil before. But the evil-doers have never seen the American people in action before, either - and they're about to find out.

President Bush's Address to a Joint Session of Congress and the American People (September 20, 2001)

On September the 11th, enemies of freedom committed an act of war against our country. Americans have known wars -- but for the past 136 years, they have been wars on foreign soil, except for one Sunday in 1941. Americans have known the casualties of war -- but not at the center of a great city on a peaceful morning. Americans have known surprise attacks -- but never before on thousands of civilians. All of this was brought upon us in a single day -- and night fell on a different world, a world where freedom itself is under attack. [...] Americans are asking, why do they hate us? They hate what we see right here in this chamber -- a democratically elected government. Their leaders are self-appointed. They hate our freedoms -- our freedom of religion, our freedom of speech, our freedom to vote and assemble and disagree with each other. [...] These terrorists kill not merely to end lives, but to disrupt and end a way of life. With every atrocity, they hope that America grows fearful, retreating from the world and forsaking our friends. They stand against us, because we stand in their way.

We are not deceived by their pretenses to piety. We have seen their kind before. They are the heirs of all the murderous ideologies of the $20^{\text {th }}$ century. By sacrificing human life to serve their radical visions -- by abandoning every value except the will to power -- they follow in the path of fascism, and Nazism, and totalitarianism. And they will follow that path all the way, to where it ends: in history's unmarked grave of discarded lies. [...]

Our response involves far more than instant retaliation and isolated strikes. Americans should not expect one battle, but a lengthy campaign, unlike any other we have ever seen. It may include dramatic strikes, visible on TV, and covert operations, secret even in success. We will starve terrorists of funding, turn them one against another, drive them from place to place, until there is no refuge or no rest. And we will pursue nations that provide aid or safe haven to terrorism. Every nation, in every region, now has a decision to make. Either you are with us, or you are with the terrorists. From this day forward, any nation that continues to harbor or support terrorism will be regarded by the United States as a hostile regime. This is not, however, just America's fight. And what is at stake is not just America's freedom. This is the world's fight. This is civilization's fight. This is the fight of all who believe in progress and pluralism, tolerance and freedom.

And in our grief and anger we have found our mission and our moment. Freedom and fear are at war. The advance of human freedom -- the great achievement of our time, and the great hope of every time -- now 
depends on us. Our nation -- this generation -- will lift a dark threat of violence from our people and our future. We will rally the world to this cause by our efforts, by our courage. We will not tire, we will not falter, and we will not fail. $[\ldots]$

\section{George W. Bush' s January 29, 2002 State of the Union Speech}

States like these, and their terrorist allies, constitute an axis of evil, arming to threaten the peace of the world. By seeking weapons of mass destruction, these regimes pose a grave and growing danger. They could provide these arms to terrorists, giving them the means to match their hatred. They could attack our allies or attempt to blackmail the United States. In any of these cases, the price of indifference would be catastrophic...

We'll be deliberate, yet time is not on our side. I will not wait on events while dangers gather. I will not stand by as peril draws closer and closer. The United States of America will not permit the world's most dangerous regimes to threaten us with the world's most destructive weapons

Our war on terror is well begun, but it is only begun. This campaign may not be finished on our watch, yet it must be and it will be waged on our watch.

We can't stop short. If we stopped now, leaving terror camps intact and terror states unchecked, our sense of security would be false and temporary. History has called America and our allies to action, and it is both our responsibility and our privilege to fight freedom's fight. [...]

In a single instant, we realized that this will be a decisive decade in the history of liberty -- that we have been called to a unique role in human events. Rarely has the world faced a choice more clear or consequential.

\section{George W. Bush (January 30, 2002)}

You know, you've heard me talk about this probably, but I really, truly view this as a conflict between good and evil. And there really isn't much middle ground-like none. The people we fight are evil people...

Either you are with us or you're against us. Either you're on the side of freedom and justice or you aren't.

\section{George W. Bush: Commencement Address at the United States Military Academy at West Point, New York (June 1, 2002)}

For much of the last century, America's defense relied on the Cold War doctrines of deterrence and containment. In some cases, those strategies still apply. But new threats also require new thinking. Deterrence -- the promise of massive retaliation against nations -- means nothing against shadowy terrorist networks with no nation or citizens to defend. Containment is not possible when unbalanced dictators with weapons of mass destruction can deliver those weapons on missiles or secretly provide them to terrorist allies. [...]

for preemptive action when necessary to defend our liberty and to defend our lives.

All nations that decide for aggression and terror will pay a price. We will not leave the safety of America and the peace of the planet at the mercy of a few mad terrorists and tyrants. We will lift this dark threat from our country and from the world.

Because the war on terror will require resolve and patience, it will also require firm moral purpose. In this way our struggle is similar to the Cold War. Now, as then, our enemies are totalitarians, holding a creed of power with no place for human dignity. Now, as then, they seek to impose a joyless conformity, to control every life and all of life. [...]

Some worry that it is somehow undiplomatic or impolite to speak the language of right and wrong. I disagree. Different circumstances require different methods, but not different moralities. Moral truth is the same in every culture, in every time, and in every place. Targeting innocent civilians for murder is always and everywhere wrong. Brutality against women is always and everywhere wrong. There can be no neutrality between justice and cruelty, between the innocent and the guilty. We are in a conflict between good and evil, and America will call evil by its name. By confronting evil and lawless regimes, we do not create a problem, we reveal a problem. And we will lead the world in opposing it.

\section{George W. Bush: State of the Union Address (January 28, 2003)}

This nation can lead the world in sparing innocent people from a plague of nature. And this nation is leading the world in confronting and defeating the man-made evil of international terrorism.

Now, in this century, the ideology of power and domination has appeared again, and seeks to gain the ultimate weapons of terror. Once again, this nation and all our friends are all that stand between a world at peace, and a world of chaos and constant alarm. Once again, we are called to defend the safety of our people, and the hopes of all mankind. And we accept this responsibility.

Americans are a free people, who know that freedom is the right of every person and the future of every nation. The liberty we prize is not America's gift to the world, it is God's gift to humanity. 
We Americans have faith in ourselves, but not in ourselves alone. We do not know -- we do not claim to know all the ways of Providence, yet we can trust in them, placing our confidence in the loving God behind all of life, and all of history.

\section{George W. Bush: Speech at the National Endowment for Democracy (October 6, 2005)}

In this new century, freedom is once again assaulted by enemies determined to roll back generations of democratic progress. Once again, we're responding to a global campaign of fear with a global campaign of freedom. And once again, we will see freedom's victory.

The images and experience of September the 11th are unique for Americans. Yet the evil of that morning has reappeared on other days, in other places -- in Mombasa, and Casablanca, and Riyadh, and Jakarta, and Istanbul, and Madrid, and Beslan, and Taba, and Netanya, and Baghdad, and elsewhere. In the past few months, we've seen a new terror offensive with attacks on London, and Sharm el-Sheikh, and a deadly bombing in Bali once again. All these separate images of destruction and suffering that we see on the news can seem like random and isolated acts of madness; innocent men and women and children have died simply because they boarded the wrong train, or worked in the wrong building, or checked into the wrong hotel. Yet, while the killers choose their victims indiscriminately, their attacks serve a clear and focused ideology, a set of beliefs and goals that are evil, but not insane.

Some call this evil Islamic radicalism; others, militant Jihadism; still others, Islamo-fascism. Whatever it's called, this ideology is very different from the religion of Islam. This form of radicalism exploits Islam to serve a violent, political vision: the establishment, by terrorism and subversion and insurgency, of a totalitarian empire that denies all political and religious freedom. These extremists distort the idea of jihad into a call for terrorist murder against Christians and Jews and Hindus -- and also against Muslims from other traditions, who they regard as heretics. [...] These operatives, fighting on scattered battlefields, share a similar ideology and vision for our world.

Some might be tempted to dismiss these goals as fanatical or extreme. Well, they are fanatical and extreme -and they should not be dismissed. Our enemy is utterly committed. As Zarqawi has vowed, "We will either achieve victory over the human race or we will pass to the eternal life." And the civilized world knows very well that other fanatics in history, from Hitler to Stalin to Pol Pot, consumed whole nations in war and genocide before leaving the stage of history. Evil men, obsessed with ambition and unburdened by conscience, must be taken very seriously -- and we must stop them before their crimes can multiply. [...]

Over the years these extremists have used a litany of excuses for violence -- the Israeli presence on the West Bank, or the U.S. military presence in Saudi Arabia, or the defeat of the Taliban, or the Crusades of a thousand years ago. In fact, we're not facing a set of grievances that can be soothed and addressed. We're facing a radical ideology with inalterable objectives: to enslave whole nations and intimidate the world. No act of ours invited the rage of the killers -- and no concession, bribe, or act of appeasement would change or limit their plans for murder.

The murderous ideology of the Islamic radicals is the great challenge of our new century. Yet, in many ways, this fight resembles the struggle against communism in the last century. Like the ideology of communism, Islamic radicalism is elitist, led by a self-appointed vanguard that presumes to speak for the Muslim masses. Bin Laden says his own role is to tell Muslims, quote, "what is good for them and what is not." And what this man who grew up in wealth and privilege considers good for poor Muslims is that they become killers and suicide bombers. He assures them that his -- that this is the road to paradise -- though he never offers to go along for the ride.

Like the ideology of communism, our new enemy teaches that innocent individuals can be sacrificed to serve a political vision. And this explains their cold-blooded contempt for human life. We've seen it in the murders of Daniel Pearl, Nicholas Berg, and Margaret Hassan, and many others. In a courtroom in the Netherlands, the killer of Theo Van Gogh turned to the victim's grieving mother and said, "I do not feel your pain -- because I believe you are an infidel." And in spite of this veneer of religious rhetoric, most of the victims claimed by the militants are fellow Muslims. [...]

Like the ideology of communism, our new enemy pursues totalitarian aims. Its leaders pretend to be an aggrieved party, representing the powerless against imperial enemies. In truth they have endless ambitions of imperial domination, and they wish to make everyone powerless except themselves. Under their rule, they have banned books, and desecrated historical monuments, and brutalized women. They seek to end dissent in every form, and to control every aspect of life, and to rule the soul, itself. While promising a future of justice and holiness, the terrorists are preparing for a future of oppression and misery.

Like the ideology of communism, our new enemy is dismissive of free peoples, claiming that men and women who live in liberty are weak and decadent. Zarqawi has said that Americans are, quote, "the most cowardly of God's creatures." But let's be clear: It is cowardice that seeks to kill children and the elderly with car bombs, and cuts the throat of a bound captive, and targets worshipers leaving a mosque. It is courage that liberated more 
than 50 million people. It is courage that keeps an untiring vigil against the enemies of a rising democracy. And it is courage in the cause of freedom that once again will destroy the enemies of freedom.

And Islamic radicalism, like the ideology of communism, contains inherent contradictions that doom it to failure. By fearing freedom -- by distrusting human creativity, and punishing change, and limiting the contributions of half the population -- this ideology undermines the very qualities that make human progress possible, and human societies successful. The terrorists are as brutal an enemy as we've ever faced. They're unconstrained by any notion of our common humanity, or by the rules of warfare. No one should underestimate the difficulties ahead, nor should they overlook the advantages we bring to this fight.

\section{APPENDIX 2}

\section{Expressions of American Exceptionalism}

"We must consider that we shall be as a City upon a Hill, the eyes of all people are upon us." John Winthrop, "A Model of Christian Charity" (1630)

"It will be worthy of a free, enlightened, and at no great distant period a great nation to give to mankind the magnanimous and too novel example of a people always guided by an exalted justice and benevolence."

George Washington, Farewell Address, 17 September 1796

"Destiny has laid upon our country the responsibility of the free world's leadership."

Dwight D. Eisenhower, First Inaugural Address, 20 January 1953

"Let every nation know, whether it wishes us well or ill, that we shall pay any price, bear any burden, meet any hardship, support any friend, oppose any foe to assure the survival and success of liberty.... [T]he energy, the faith, the devotion which we bring to this endeavor will light our country and all who serve it - and the glow from that fire can truly light the world."

John F. Kennedy, Inaugural Address, 20 January 1961

"Our [foreign] policy is designed to serve mankind."

Jimmy Carter, commencement address at University of Notre Dame, 22 May 1977

"Americans resort to force only when we must. We have never been aggressors. We have always struggled to defend freedom and democracy. We have no territorial ambitions. We occupy no territories."

Ronald Reagan, State of the Union Address, 25 January 1984

"The past few days when I've been at that window upstairs, I've thought a bit of the 'shining city upon a hill.' The phrase comes from John Winthrop, who wrote it to describe the America he imagined. What he imagined was important because he was an early Pilgrim, an early freedom man. He journeyed here on what today we'd call a little wooden boat; and like the other Pilgrims, he was looking for a home that would be free. And how stands the city on this winter night? More prosperous, more secure, and happier than it was 8 years ago. But more than that: After 200 years, two centuries, she still stands strong and true on the granite ridge, and her glow has held steady no matter what storm. And she's still a beacon, still a magnet for all who must have freedom, for all the pilgrims from all the lost places who are hurtling through the darkness, toward home".

President Ronald Reagan, Farewell Address.

"The fact is America remains the indispensable nation. America, and only America, can make a difference between war and peace, between freedom and repression, between hope and fear [in the world]."

William Jefferson Clinton, address at George Washington University, 5 August 1996

"I am driven with a mission from God. God would tell me, 'George go and fight these terrorists in Afghanistan'. And I did. And then God would tell me 'George, go and end the tyranny in Iraq'. And I did."

George W. Bush, August 2003

"I trust God speaks through me. Without that, I couldn't do my job".

George W. Bush, Jul. 9, 2004

"God loves you, and I love you. And you can count on both of us as a powerful message that people who wonder about their future can hear."

George W. Bush, Mar. 3, 2004 


\section{Works Cited}

[1]. Blakley, Johanna. "Entertainment Goes Global: Mass Culture in Transforming World", The Norman Lear Center Publications, January 2001, pp. 13-17.

[2]. Bush, George. A Charge to Keep: My Journey to the White House. NY: HarperCollins Publishers, 2000.

[3]. Coe, Kevin, Domke, David, Graham, Erica, John, Sue, and Pickard, Victor. "No Shades of Gray: The Binary Discourse of George W. Bush and an Echoing Press", Journal of Communication, January 2006, pp. 234-252.

[4]. Coe, Kevin. The Language of Freedom in the American Presidency, 1933-2006. Washington, D.C.: Collet, Tanja and Najem, Tom. Word Choices in Post-9/11 Speeches and the Identity Construction of the Other (http://www.cpsa-acsp.ca/papers-2005/Najem.pdf)

[6]. Cowen, Tyler. "French Kiss-Off: How protectionism has hurt French films", Reason, July 1998, pp. 7-10.

[7]. Fukuyama, Francis. Trust: The Social Virtues and the Creation of Prosperity. N.Y.: The Free Press, 1995.

[8]. Graham, Philip, Keenan, Thomas and Dowd, Anne-Maree. "A call to arms at the End of History: A discourse-historical analysis of George W. Bush's declaration of war on terror", Discourse \& Society, 2004, pp. 199-221.

[9]. Kegley, Charles and Wittkopf, Eugene. American Foreign Policy: Pattern and Process. New York: St. Martin's Press, 1991.

[10]. Sullivan, Andrew. The Conservative Soul. NY: HarperCollins Publishers, 2006. 